\title{
Spatial and Temporal Analysis of Land Use Change for 11 years (2004-2014) in Sub-Watershed Sumpur Singkarak
}

\author{
Edwin $^{\#}$, Amrizal Saidi ${ }^{*}$, Aprisal ${ }^{*}$, Yulnafatmawita $^{*}$ and Ita Carolita ${ }^{1}$

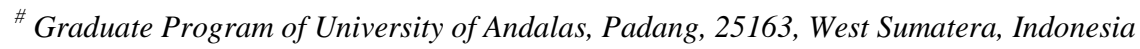 \\ E-mail: edwin@faperta.unand.ac.id \\ * Soil Department, Faculty of Agriculture, University of Andalas, Padang, 25163, Indonesia \\ E-mail: amrizal.saidi@gmail.com; aprisadunand@yahoo.co.id; yulna_fatmawita@yahoo.com \\ * Remote Sensing Application Centre, Indonesian National Aeronautic and Space Institute, Jakarta,13721, Indonesia \\ E-mail: Ita.carolita@yahoo.com
}

\begin{abstract}
The pressure of population growth and the economy has an impact on changes in land use in Sub-watershed Sumpur Singkarak West Sumatra, Indonesia. Changes in land use are analyzed spatially and temporally using satellite imagery Landsat TM 7 and 8 (resolution $30 \mathrm{~m}$ ) that has been in the interpretation of 2004 to 2014 . The analysis is done by comparing the changes in land use in the area of forest, farming and settlement. From the analysis it can be concluded that there has been a decline in forest area of 128 ha $(1.6 \%)$, an increase in mixed-farming area of 146 ha $(16.1 \%)$, an increase in settlement area of 143 ha $(26 \%)$ for 11 years in Subwatershed. In 2011, a change of 3125 ha of rice-paddy which have been changed become dry land an area of 2645 ha. This is due to the farming community, prefer to plant horticulture and crop plant from the rice plant.In the protected forest area has been used for settlement area of $\mathbf{1 . 3 7}$ ha and for dry land area of $\mathbf{1 1 . 4 1}$ ha. In the tourist nature reserve forest areas have been used for rice paddy area of 0:33 ha and for dry land area of 42.91 ha.
\end{abstract}

Keywords — Land-Use Change; Satellite image interpretation; Sub-Watersheed Sumpur Singkarak

\section{INTRODUCTION}

Land use change is a complex dynamic process, which is interconnected between the natural environment by human beings who have a direct impact on soil, water, atmosphere and other issues of global environmental interests [1][2][3][4]. Land use change is due to population growth, and the development of construction activity. Changes in land use also occurs in watersheds close to the center of development growth. The result will disrupt the hydrological system of watersheds [5] [6],[7],[8]

To evaluate land use changes can be done quickly by using remote sensing technology and geographic information systems to observe spatially and temporally [6][9],[10],[11]

Remote sensing is the science and art of obtaining information about an object or phenomenon by analyzing the data obtained by using the tool without direct contact with the object, area or phenomenon to be studied [12]. Images is one of the results of the recording process with a remote sensing satellite. The image interpretation can be done visually or digitally. The principle of object recognition in visual imagery depends on the characteristics or attributes depicted in the image.

For image interpretation can be performed using a geographic information system (GIS). Currently the use of GIS has evolved into a wide range of knowledge that can be integrated with spatial information. Among them is to analyze changes in land use / land cover using satellite imagery spatial data. Advantages of satellite images of the other image is that it can provide spatial data with different levels of sharpness of resolution and the long dimension. Hence the analysis of land use changes / land cover more appropriate use of satellite imagery data.[10][12].

Analysis of land use changes / land cover can be done by creating a matrix of land use changes / land cover based on the results of GIS analysis of the observed or studied. Matrix of land cover changes can be seen vast changes that occur every year. 


\section{MATERIAL AND METHODS}

\section{A. Study Area}

Sub watersheds Sumpur Singkarak located in Tanah Datar and Padang Panjang West Sumatra province of Indonesia. The location is situated between Mount Merapi and Lake Singkarak and an area of 15478 ha. Geographically the study area lies in $0^{\circ} 23^{\prime} 20$ "- $0^{\circ} 34^{\prime} 18^{\prime \prime}$ South latitude and $100^{\circ}$ 26 ' 42 " - $100^{\circ} 27^{\prime} 49^{\prime \prime}$ East longitude. This area is a protected forest area. forest conservation areas, agricultural areas, water resources and tourism area.

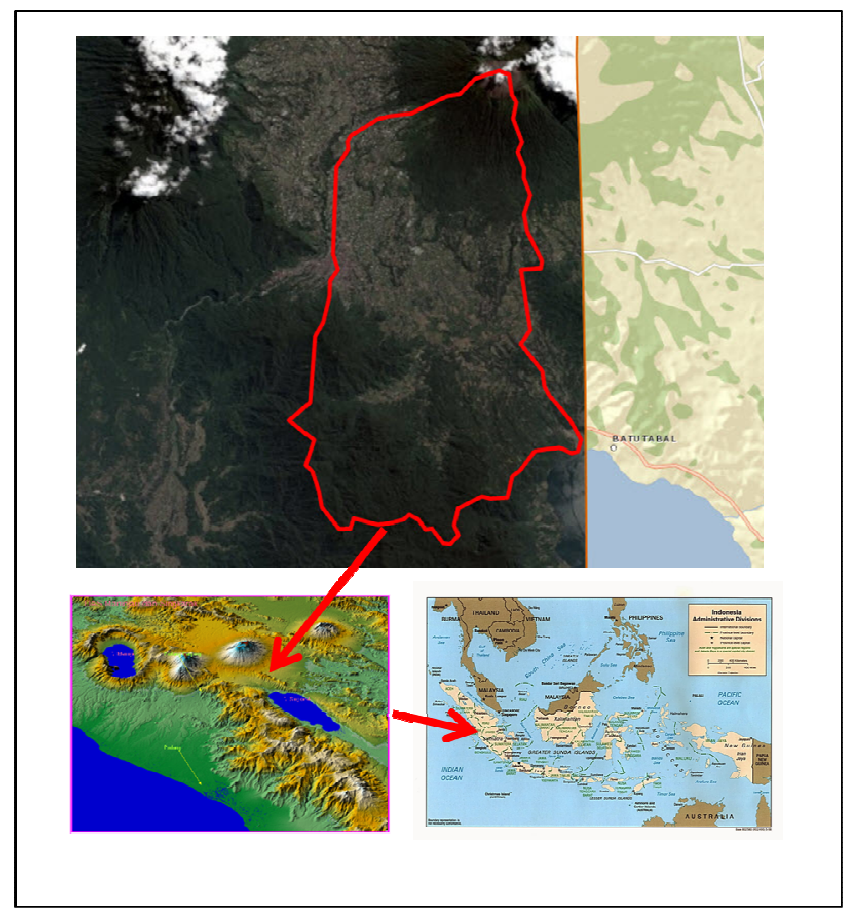

Fig. 1. Location Sub-watershed study Sumpur Singkarak, West Sumatra, Indonesia.

\section{B. Data Sources and Processing}

The data used are images of Landsat 5 TM (2004 and 2006), Landsat 7 TM (2008, 2009 and 2011) and Landsat TM 8 (2014) in the form of raster. Digital elevation model (DEM) Shuttle Radar Topography Mission (SRTM) in raster form [13]. Visual map of the earth in the form of vector [14]. Map of administrative boundaries in the form of a vector [15]. Map of forest area in the form of vector [16].

Satellite image processing using ArcGIS 10.1 software support. Geometry correction on satellite imagery aims to correct satellite imagery to match the actual coordinate position on the earth. Geometry correction process is done by creating Ground Control Point (GCP) at the control point which is a satellite image of the same point on the Earth in such a vector digital map Indonesia by referring to roads and rivers, for example, at the intersection of roads and rivers.

After geometric correction on the satellite image, then continued with radiometric correction by histogram adjustment using ER Mapper 7.0 software. The radiometric correction function to minimize errors caused satellite detectors influence or the influence of atmospheric interference. Atmosphere as a conductor media electromagnetic waves from the sun have a considerable influence on the satellite image, the form of scattering. Due to the atmospheric effects, brightness values in the digital image does not describe the actual state of the object.

\section{Satellite Image Interpretation}

This process is the analysis and identification of objects using ArcGIS 10.1 software (linsensi Space Agency and National Aviation, Indonesia) [13]. Some points to consider in the process of image interpretation such as hue or color (tone /color), form (shape), size (size), roughness (texture), pattern (pattern), shadow (shadow), the site (site), associations (association) and the convergence of evidence. Interpretation and image classification is done using a supervised classification (supervised classification) with Maximum Likelihood method using a combination of composite band for vegetation analysis of land use. Use classification used 6 groups, namely; forest, mixed farmed, rice paddy, dry land, open land, and settlements.

Forests are areas overgrown with trees whose growth rate reached a maximum. Definition of forested areas does not mean the forest area, but its standing forest area existing natural forests and production forests. Mixed farms is an area or areas of land cultivated for gardens with no dominant species of plants that are cultivated or cultivated in monocultures. Paddy is cultivated area for agricultural activities wetlands, flooded periodically or continuously with rice vegetation. Dry land is an area that never irrigated agriculture, which is planted with short lifespan species of plants (vegetables and crop plant) and perennials that may exist on the dike-dike. Open land is an area of no vegetation cover and buildings, formed because of poor physical condition, due to natural processes (erosion, natural disasters, etc.), and not as a result of land clearing.Settlement is the area that is used as a living environment or residential environment and the activities that support life and livelihood, as well as a part of the environment outside protected areas, both of which are urban and rural settlements.

Land use analysis results are validated through field inspections. Then proceed with the digitization process for making land use maps in 2004, 2006, 2008, 2009, 2011 and 2014

\section{Analysis of Land Use Change}

Analysis of land use changes in an area merupaka a process to identify differences in the presence of an object or phenomenon observed at different times. Analysis of land use changes requires a temporal spatial data. Spatial data derived from the interpretation of satellite imagery as well as from government agencies, analyzed using geographic information systems. Analysis of the spatial and temporal changes in land use sub-watershed Sumpur Singkarak done by comparing land use changes in 2004, 2006, 2008, 2009, 2011 and 2014. The comparison between the area of land use can be observed changes in each class of land use for 11 years. This analysis was also carried out on the overlay between land use maps in 2014 to map the forest area, to examine whether there is land cultivation and settlement into the protected forest area or forest preserves tour [16]. 


\section{RESULTS AND ANALYSIS}

\section{A. Result}

Based on the results of image interpretation of land use sub-watershed Sumpur Singkarak, the importance of the land use map. Classes are divided into forest, mixed farmed, rice paddy, dry land, open land and settlements. Temporally can be seen in Figure 2 land use changes in 2004, 2006,2008,2009,20011 and 2014 as well as the data can be seen in Table 1 and Figure 3.

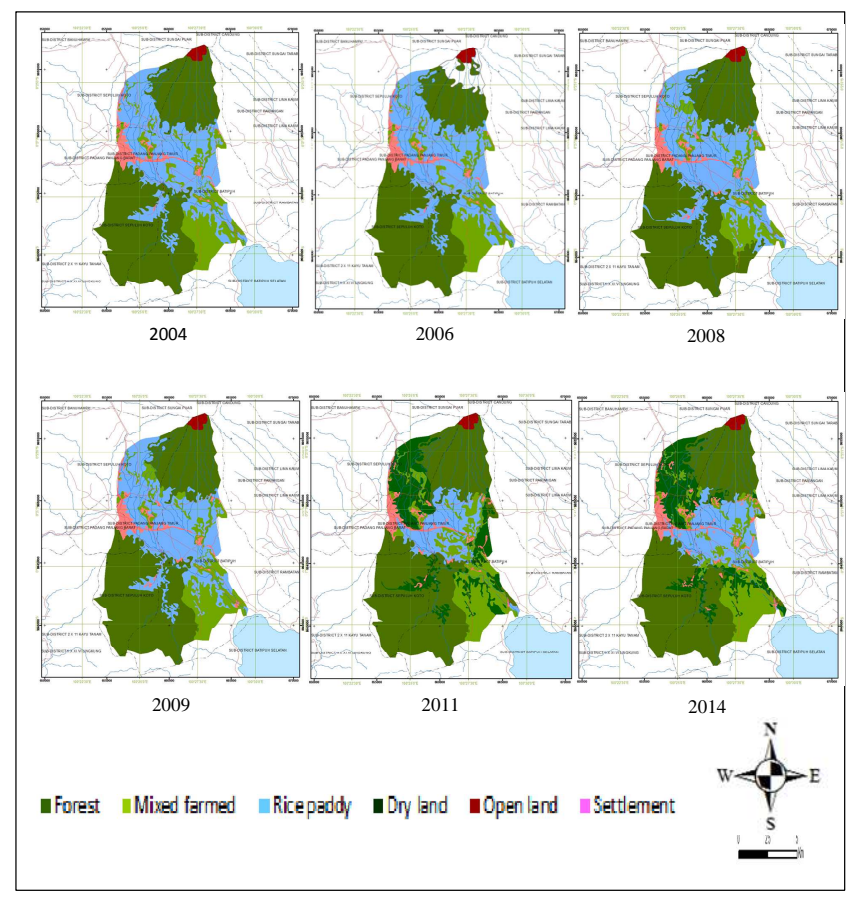

Fig. 2. Land use change I n sub-watershed Sumpur Singkarak (2004-2014)

TABEL I

AREA AND PERcEntage LAND Use Change In Sub-WATERSHED SUMPUR SINGKARAK (2004-2014).

\begin{tabular}{|l|r|r|r|r|r|r|r|r|r|r|r|r|}
\hline \multirow{2}{*}{ Classes } & \multicolumn{2}{|c|}{2000} & \multicolumn{2}{c|}{2006} & \multicolumn{2}{c|}{2008} & \multicolumn{2}{|c|}{2009} & \multicolumn{2}{|c|}{2011} & \multicolumn{2}{|c|}{2014} \\
\cline { 2 - 12 } & (ha) & (\%) & (ha) & (\%) & (ha) & (\%) & (ha) & (\%) & (ha) & (\%) & (ha) & (\%) \\
\hline Forest & 7,836 & 50.6 & 7,767 & 50.2 & 7,995 & 51.7 & 7,788 & 50.3 & 7,995 & 51.7 & 7,708 & 49.8 \\
Mixed farmed & 2,025 & 13.1 & 2,025 & 13.1 & 1,730 & 11.2 & 2,140 & 13.8 & 2,483 & 16 & 2,351 & 15.2 \\
Rice paddy & 4,930 & 31.9 & 4,999 & 32.3 & 5,019 & 32.4 & 4,810 & 31.1 & 1,685 & 10.9 & 2,255 & 14.6 \\
Dry land & 0 & 0 & 0 & 0 & 0 & 0 & 0 & 0 & 2,645 & 17.1 & 2,334 & 15.1 \\
Open land & 135 & 0.9 & 135 & 0.9 & 135 & 0.9 & 135 & 0.9 & 135 & 0.9 & 135 & 0.9 \\
Settlement & 552 & 3.6 & 552 & 3.6 & 599 & 3.9 & 605 & 3.9 & 536 & 3.5 & 695 & 4.5 \\
\hline
\end{tabular}

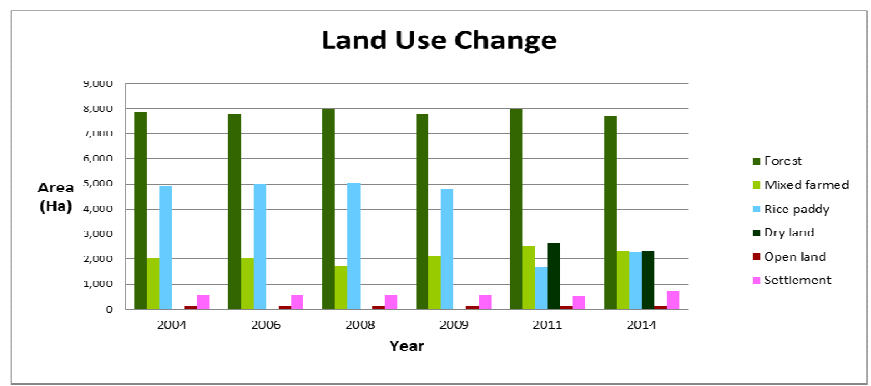

Fig. 3. Direction of land use change in sub-watershed Sumpur Singkarak (2004-2014)

\section{B. Analysis}

In Figure 2 can be seen visually land use changes between 2004 and 2014. In Table 1 and Figure 3 can be seen the data area of land use that occurred between 2004 and 2014.

Reduced forest area covering an area of 128 ha (1.6\%), when compared to 2004 by 2014 . But overall forest in sub watersheds Sumpur Singkarak already exceeded $30 \%$ of green open space for environmental sustainability goals [17]. Fluctuations in forest area change in this sub-watersheds, occurred because due to forest rehabilitation program undertaken by the Government and also due to the relatively faster forest plants grown in the tropics. Sub watersheds Sumpur Singkarak including fertile region with rainfall of $2347 \mathrm{~mm} /$ year with an average monthly rainfall above> $100 \mathrm{~mm}$ and temperatures above $180 \mathrm{C} \mathrm{[18]} \mathrm{[19].}$

In the sub-watersheds, there are a protected forest area covering an area of 1345.60 ha and forest preserves tourist area of 3955.04 ha [16]. From the resulting overlay between 2014 land use maps with maps of forest area, was seen in the protected forest has been used by the community for the settlement area of 1.37 ha and dry land area 11,41 ha. Forest preserves on tour has been used for rice paddy area 0,33 ha and for dry land area 42.91 ha. This needs to be addressed by the local government to provide guidance or counseling so that people do not use land in the protected areas and nature reserves tourist.

The use of land for rice paddy from 2004 to 2009, relatively few changes. However, in 2011 a decline in rice paddy area of 3125 ha $(65 \%)$. This is due to many community farmers to switch from rice paddy into a business venture vegetables and crop plant, because it is economically more profitable. It can also be seen an increase in dry land in 2011 to 2645 ha in 2014 to 2334 ha.

Open land is the land of the caldera mountains Merapi, which can not be overgrown with plants, where the area is relatively fixed 135 ha.

Settlements increased area of 143 ha (26\%) from 2004 to 2014. Among them is due to population growth sub-districts $\mathrm{X}$ Koto $0.51 \%$, sub-district Batipuh $0.04 \%$, su-districts South Batipuh 0.20\% and sub-district East Padang Panjang $0,64 \%$. Besides, the economic growth of district Tanah Datar $5.93 \%$ and Padang Panjang $6.14 \%$, also caused the increase settlement [20] [21]. This settlement growth also need to watch out especially for areas of protected forest and nature reserve which is a conservation area tourist to environmental sustainability.

\section{CONCLUSIONS}

From the analysis of spatial and temporal sub watersheds Sumpur Singkarak from 2004 until 2014, there has been a decline in forest area of 128 ha (1.6\%), improvement of agricultural mix farmed of 146 ha $(16.1 \%)$, an increase settlements area of 143 ha $(26 \%)$.

In 2011 , there were 3125 ha of rice paddy field change them have become dry land an area of 2645 ha. This is due to the farming community, prefer to grow vegetables and other crops land.

In the protected forest area of 1.37 ha has been used for settlements and 11,41 ha to dry land. In the tourist area of nature reserve has been used by the community to rice paddy 
of 0,33 ha and dry land of 42.91 ha. This should be done socialization and counseling to people in Sub watershed Sumpur Singkarak

\section{REFERENCES}

[1] Buchar, S., Bhuchar, S., Xing, M., \& Kothyari, B. (2007). Land use Change and Its Impact on Hydro-Ecological Linkages in Himalayan Watersheds. 48(2), : 151-161.

[2] Kooman, E., Stillwell, J., Bakema, A., \& Scholten, H. (2007) Modelling Land-Use Change Progress and Application. Springer..

[3] Yi, X., Chao-Fu, W., \& Ke, Y. (2011). Recent 10-year land use change and evaluation of their performance, in Chongqing, China. Energy Procedia, 5, 457-461.

[4] Daye, D. D., \& Healey, J. R. (2015). Impacts of Land-use Change on Sacred Forests at the Landscape Scale. 3, 349-358.

[5] COSKUN, H. G., \& YALCIN, G. (2014). Analysis of Land Use Change and Urbanization in Büyükçekmece Watershed (Istanbul, Turkey). 3(7)

[6] Iqbal, M. F., \& Khan, I. A. (2014). Spatiotemporal Land Use Land Cover change analysis and erosion risk mapping of Azad Jammu and Kashmir, Pakistan. 17, 209-229.

[7] Nugroho, P., Marsono, D., Sudira, P., \& Suryatmojo, H. (2013). Impact of Land-Use Changes on Water Balance. Procedia Environmental Sciences, 17, 256 - 262.

[8] Tang, Z., Engel, B., Pijanowski, B., \& Lim, K. (2005). Forecasting Land Use Change and Its Environmental Impact at a Watershed Scale. 76, 35-45.

[9] Dubovyk, O., Menz, G., Conrad, C., Kan, E., Machwitz, M., \& Khamzina, A. (2013). Spatio-temporal Analyses of Cropland Degradation in the Irrigated Lowlands of Uzbekistan Usingremotesensing and logistic regression modeling. 185, 4775-4790.
[10] Erener, A., Düzgün, S., \& Yalciner, A. C. (2012). Evaluating Land Use/Cover Change with Temporal Satellite Data and Information Systems. 1, 385-389.

[11] Meiyappan, P., Dalton, M., O'Neill, B. C., \& Jain, A. K. (2014). Spatial Modeling of Agricultural Land Use Change at Global Scale. 291, 152-174

[12] Lillesand, T. M., Kiefer, R. W., \& Chipman, J. (2008). Remote Sensing and Image Interpretation. USA: John Wiley \& Sons Inc, http://www.amazon.com/Remote-Sensing-Interpretation-ThomasLillesand/dp/0470052457\#reader_0470052457.

[13] Indonesian National Institute of Aeronoutics and Space. (2015). Landsat Data. Remote Sensing Technology and Data Centre,

[14] Geospatial Information Agency. (2012). Visual Map of The Earth Bogor, West Java.

[15] Regional Development Planning Board Tanah Datar. (2014). Map Administration Tanah Datar. Batusangkar.

[16] Forestry Agency, West Sumatra Province, Indonesia. (n.d.). Map Forests of West Sumatra Province, Indonesia. Padang, 2014.

[17] The Government of the Republic of Indonesia. (2008). Indonesian Government Regulation Number 26 of 2008 on the National Spatial Plan.

[18] Center for Agricultural Extension Station Batipuh, Tanah Datar (2014). Rainfall Data. Batusangkar: Agricultural Office of Tanah Datar District .

[19] Woodward, S. (2008, Agustus 14). Wikipedia. Retrieved September 3, 2015, from Hutan hujan tropika: https://id.wikipedia.org/wiki/

[20] The Central Bureau of Statistics of Padang Panjang. (2014). Padang Panjang in Figures 2014. Padang Panjang: The Central Bureau of Statistics of Padang Panjang.

[21] The Central Bureau of Statistics of Tanah Datar. (2014). Tanah Datar in Figures 2014. The Central Bureau of Statistics of Tanah Datar. 